\title{
External Morphology of the Adult of Heraclides anchisiades capys (Hübner, [1809]) (Lepidoptera - Papilionidae) I. Head, Cephalic Appendages and Cervical Region
}

\author{
Luis Anderson Ribeiro Leite ${ }^{*}$, Mirna Martins Casagrande and Olaf Hermann Hendrik \\ Mielke \\ Departamento de Zoologia; Setor de Ciências Biológicas; Universidade Federal do Paraná; C. P.: 19020; 81531 - \\ 980; Curitiba - PR - Brasil
}

\begin{abstract}
The purpose of this study was to highlight the morphological components of the head, its appendages and the cervical region of the adults of Heraclides anchisiades capys (Hübner, [1809]), looking for a comparative focus with the other Papilionoidea and Hesperioidea. The most relevant morphological characters were: presence of transclipeal band, laterofacial suture in ventral view near the half of the ocular margin of convex aspect, presence of rudimental maxillary palp; union of the cervical sclerites ventromedially and ventral sclerite situated before the merger of the lateral sclerites.
\end{abstract}

Key words: Citrus, Neotropical, Papilioninae, Papilionoidea

\section{INTRODUCTION}

In Lepidoptera, butterflies are divided in two big superfamilies: Hesperioidea with about 2,400 species and Papilionoidea with approximately 5,500 species; both are estimates for the Neotropical region (Lamas, 2004). Some of the synapomorphies that identify both groups can be found on the head, for example, the space between the base of the antenna insertion, while on Hesperioidea this space is measurable, on Papilionoidea the base of the antennal alveolus is often very close and sometimes they touch each other medially. The shape of the antenna is also relevant since in Hesperioidea, the apical portion, club form or fuse form, curves itself in a hook shape, while in Papilionoidea it stays flat.
Studies that focus on the morphological details of the adult of Lepidoptera are of fundamental importance for the systematic knowledge of the group. In Papilionoidea, some families are approached in classical studies and in more recent ones that intend to increase the morphological information available: Nymphalidae (Ehrlich, 1958a; Casagrande, 1979b,c,d; Bilotta, 1992; 1994a,b; Bizarro et al., 2003a,b,c; C. Mielke et al., 2004a,b,c) and Lycaenidae (Sorensen, 1980; Duarte et al., 2001; Duarte, 2007). For Hesperioidea, some examples are the studies of Ehrlich (1960) and Miller (1971). The Papilionidae family, among the Papilionoidea, includes 573 species, which are predominantly tropical butterflies (Scoble, 1992), without any

*Author for correspondence: madison.2@ig.com.br 
studies of external morphology of any species from the Neotropical region before.

According to Burns et al. (2007), even in the molecular studies that indicate the species, confirmative morphological studies are preferred. The present study comprises the external morphology of the adults of both sexes of Heraclides anchisiades capys (Hübner, [1809]). Despite being a common and easy to breed specie, it does not count with studies in this regard, having the purpose of highlighting the morphological components of the head, cephalic appendages and cervical region, envisaging a comparative approach in relation to other Papilionoidea and Hesperioidea.

\section{MATERIALS AND METHODS}

Samples used in this study were brought from Rio Vermelho, São Bento do Sul, Santa Catarina and other ones were collected in gardens and parks of Curitiba and surroundings, Paraná. Adults were easily collected while visiting the flowers for food. The head and respective appendages were removed from the rest of the body and boiled in potassium hydroxide $(\mathrm{KOH}) 10 \%$ to bleach and facilitate the removal of the scales. Then the structures were observed, drawn with the aid of a stereoscopic microscope with camera lucida and interpreted. On the drawings, the option was for punctuating the sclerotized regions. The intensity of dots was directly proportional to the intensity of the sclerotinization of the regions.

The process of taking photos by the scanning electronic microscope followed standard procedure. Firstly, the pieces were dehydrated through immersion in a series of alcohols of different concentrations, 70, 80, 90 and 100\%, being in each one for 10 minutes, with a second 10 minute immersion in the absolute alcohol. After the critical point procedure the material was glued and metallized on appropriate holders.

The terminology used for the structures belonging to the head followed mostly that of Ehrlich (1958a) in the study about Danaus plexippus (Linnaeus, 1758) (Lepidoptera - Danaidae), with adaptations from the classical literature and also recent morphology studies (Snodgrass, 1935; Ehrlich, 1958b; Matsuda, 1965; Casagrande, 1979b; Sorensen, 1980; Scoble, 1992; Duarte et al., 2001; Bizarro et al., 2003a; C. Mielke et al., 2004a).

\section{RESULTS}

\section{Head (Figs 1-4, 6, 9, 20-22)}

Hypognathous, with compound eyes taking up most part of it. It does not have ocelli and has a large amount of scales that cover the totality of its surface.

On the frontal view, the compound eyes are prominent, globular shaped and glabrous and its width is superior to its height. From these, towards the fronto-clypeus, a narrow sclerite, the paraocular area between the ocular margin and laterofacial suture that is closer to the ocular margin from the subgena. Fronto-clypeus, a big sclerotized and quadrangular shaped area between the laterofacial suture, is a little smaller than the height of the compound eyes; ventrally a transclypeal band marked by grooves, is separated from the subgena by the clypeogenal section of the laterofacial suture, in which it is found as an invagination of the tegument, the anterior tentorial pit; dorsally the fronto-clypeus is not delimitated by the transfrontal suture, its separation from the vertex not being possible. Labrum and pilifer, frontally divided by the ventral medial projection of the transclypeal band, behind and in contact with the subgena, the mandibular rudiment and ventromedially the galeas. On the dorsal region of the head, the postantennal projection with chaetosema highlighted and positioned posteriorly to the antennal alveolus.

Ventrally, the ocular margin forms an open curve and the laterofacial suture, close to half of the ocular margin forms a convexity that follows until the pilifer and mandibular rudiment areas. The hypostomal subgenal suture follows from the posterior region of the head and reaches the laterofacial suture on its convexity. Rudimental maxillary palp located on the distal region of the stipe, with several bristles. Hypostomal bridge separated from the labium by the paralabial suture and from postgenal-occipital area by the hypostomal subgenal suture.

On posterior view, highlighted after the ocular margin and toward the foramen, the postgenaloccipital area takes up most part of the area, becoming weakly sclerotized toward the foramen. 

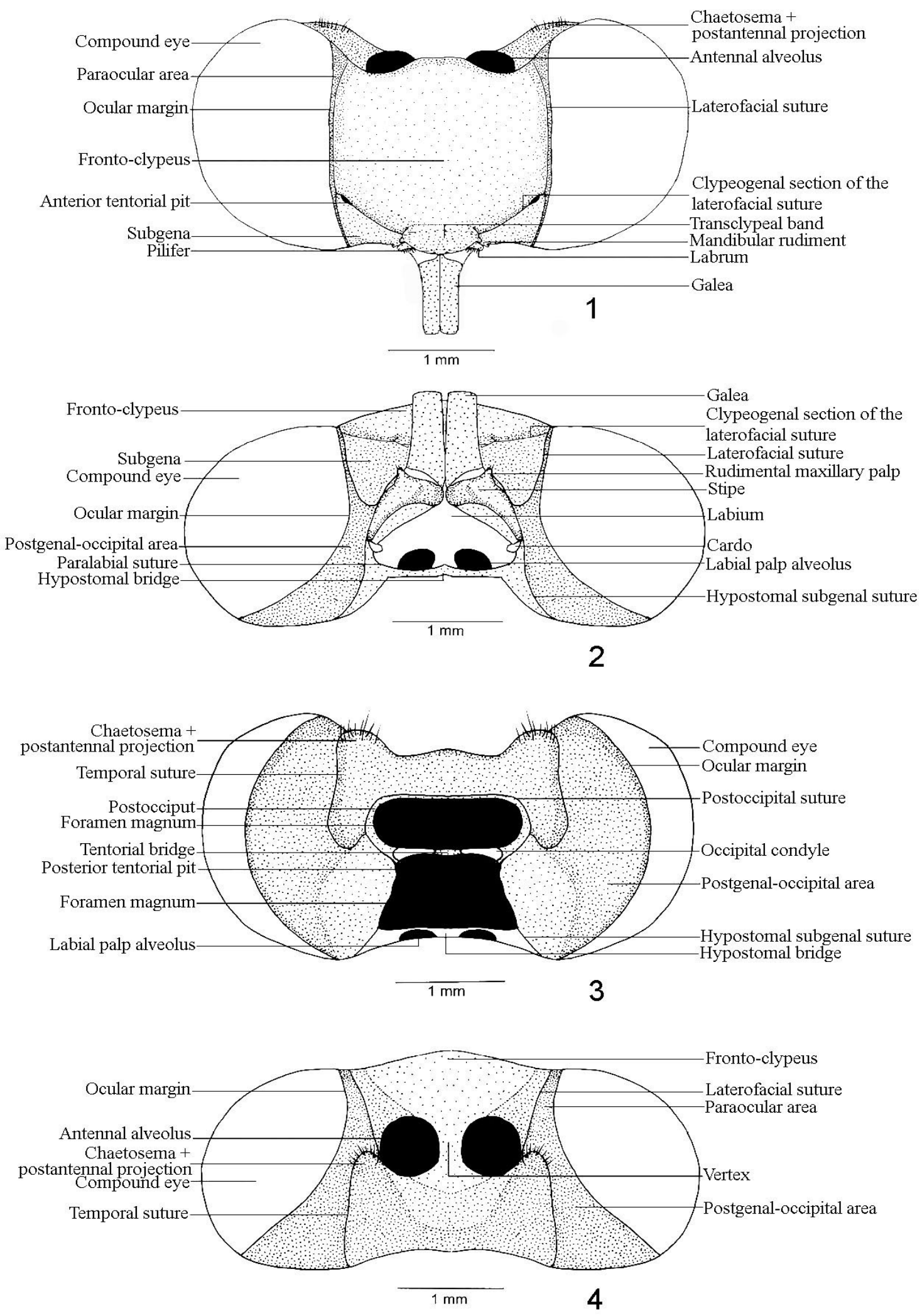

Figures 1 - 4 - Heraclides anchisiades capys: head: 1- frontal view. 2 - ventral view. 3 - posterior view. 4 - dorsal view. 
The hypostomal subgenal suture separates the postgenal-occipital area from the hypostomal bridge and ends at the inferior part of the foramen. Foramen magnum superiorly delimitated by the postocciput, medially divided by the tentorial bridge where the occipital condyle can be found, laterally by the postgenal-occipital area and ventrally by the hypostomal bridge. The postantennal projection and the chaetosema are highlighted and separated from the postgenaloccipital area through the temporal suture that extends ventrally until a little more of the half of the superior part of the foramen, showing from this point a convex aspect until the postoccipital suture.

On dorsal view, the laterofacial suture ends at the antennal alveolus. Fronto-clypeal region separated dorsally from the vertex by differences of sclerotinization since the antennal alveolus and following in parallel to the laterofacial suture, once the transfrontal suture is absent. The postantennal projection and including the chaetosema highlighted and separated from the postgenal-occipital area by the temporal suture, extending until the posterior region of the head.

On the lateral view, the compound eye is highlighted occupying most part of the head. Fronto-clypeus slightly projected.

\section{Cephalic appendages (Figs 5, 7, 8, 12-19)}

Antenna club formed and without carenae, without dimorphic characters and with little variation on the number of flagellomere, that is, males of 36 to 40 , whilst females of 38 to 41 flagellomeres. In size it has circa 8.2 times the width of the eye, that is, the distance between the subgena and the vertex. Sturdy scape and flatted dorsoventrally, with distal bristles, characterizing a sensitive region. Pedicel like a ring and with half of the size of the scape. The others form the flagellum, the first being elongated, and from the second to the sixth having reduced sizes and distally elongated like the first, the last seven flagellomeres form the club, the last with a very reduced size.

Labium less sclerotized, triangular on the central region of the proboscidial cavity, laterally limited by the stipes and posteriorly by the basis of the labial palps, by the hypostomal bridge and separated from it by the paralabial suture.

Labial palp, in lateral view, is turned upwards and its size represents approximately half of the eyes width. First segment, the biggest of the three, has
Reuter's sensitive spot in its inner face; the second segment slightly bigger than a half of the first segment and the third segment smaller and with the organ of vom Rath on the inner margin. Maxillae on the anterior region of the proboscidial cavity formed by the galea, stipe and cardo; galea not covered by scales, apical region with countless papillae irregularly distributed and circa 6.9 times bigger than the eye width; stipe on the basis of the galea with an inclined "P" shape and rudimental maxillary palp with countless bristles and located on its distal end; reduced and quadrangular cardo.

\section{Cervical Region (Figs 10 and 11)}

Reduced when compared to the other regions of the body, including two lateral sclerites and another ventral and anterior. Laterally, on the center of the membrane, the "T"-shaped cervical sclerite, articulates anteriorly with the head and posteriorly with the propleuron. Joined ventromedially more evidently on males and less sclerotized on females. Ventrally, the cervical organ as a pad covered with countless differentiated bristles. Anterior to the merger of the lateral arms is the anterior ventral cervical sclerite, rectangular and occupying the middle of the region.

\section{DISCUSSION}

Between males and females of the studied specie there were no significant differences related to the head structures.

Frontally, the clypeolabral suture, present on the other Papilionoidea (Ehrlich, 1958a; Casagrande, 1979b; Sorensen, 1980; Bizarro et al., 2003a; C. Mielke et al., 2004a) and on Hesperioidea Miller (1971), is absent in Heraclides anchisiades capys and also for Papilio demoleus Linnaeus, 1758, as observed by (Srivastava, 1957, apud Sorensen, 1980).

Transclypeal band present, such as in Hesperioidea (Miller, 1971) and few Papilionoidea (Ehrlich, 1958a; Bizarro et al., 2003a). Ehrlich (1958a) defines this band as being a region of more intense sclerotinization, occupying the fifth inferior of the fronto-clypeal sclerite. On most of the other Papilionoidea this structure seems to be absent (Casagrande, 1979b; Sorensen, 1980; Duarte et al., 2001; C. Mielke et al., 2004a). 


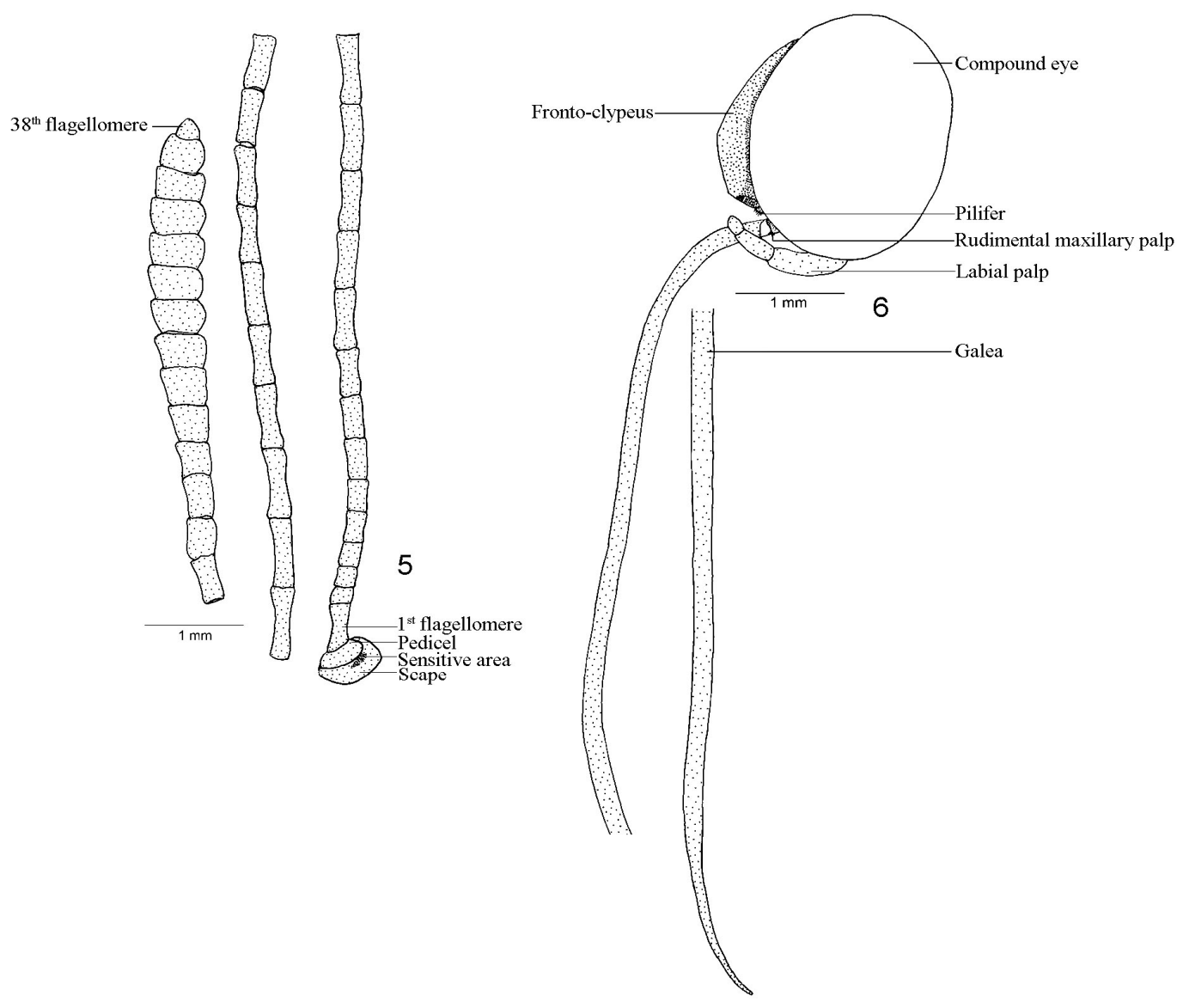

Figures 5 - 6 - Heraclides anchisiades capys: 5 - antenna. 6 - lateral view of the head.

The compound eyes are frontally highlighted with width superior than the height, differently from what occurs in Hesperioidea (Miller, 1971), also not divided in two distinct areas, an apomorphy of Hesperioidea. Fronto-clypeal region not separated from the vertex by the transfrontal suture, as present in other Papilionoidea such as Nymphalidae (Ehrlich, 1958a; Bizarro et al., 2003a; C. Mielke et al., 2004a) and Lycaenidae (Sorensen, 1980; Duarte et al., 2001).

The laterofacial suture in ventral view close to the half of the ocular margin and of convex aspect, forming a curve that reaches the pilifer and the mandibular rudiment areas, this characteristic is not observed in other Papilionoidea or in Hesperioidea.

Among the appendages, the antennas, without dimorphism and only with a slight variation on the number of flagellomeres.

Rudimental maxillary palp present, this characteristic is not observed until the present date on the other Papilionoidea, nevertheless highlighted in Hesperioidea by Miller (1971).
Differently from what occurs with many other Papilionoidea (Ehrlich, 1958a; Casagrande, 1979b; Sorensen, 1980; Bizarro et al., 2003a) and in Hesperioidea Miller (1971), the labial palp has its first segment as being the one with the longest size.

Cervical sclerite formed by two distinct parts: the lateral cervical sclerites joined ventromedially and the anterior ventral cervical sclerite, situated anteriorly to the ventral merger of the lateral cervical sclerites. Srivastava (1961) observed this situation in Papilio demoleus. This characteristic was not identified until this moment in other Papilionoidea or in Hesperioidea, where the ventral arms of the lateral sclerites do not merge. Madden (1944), however, in his study about Manduca sexta (Linnaeus, 1763) (Lepidoptera Sphingidae), refers to the merger of the ventral arms of the lateral cervical sclerites in ventromedial position, as observed on this study, but there is a lack of morphological studies in other groups to enlarge the scope of comparison. 

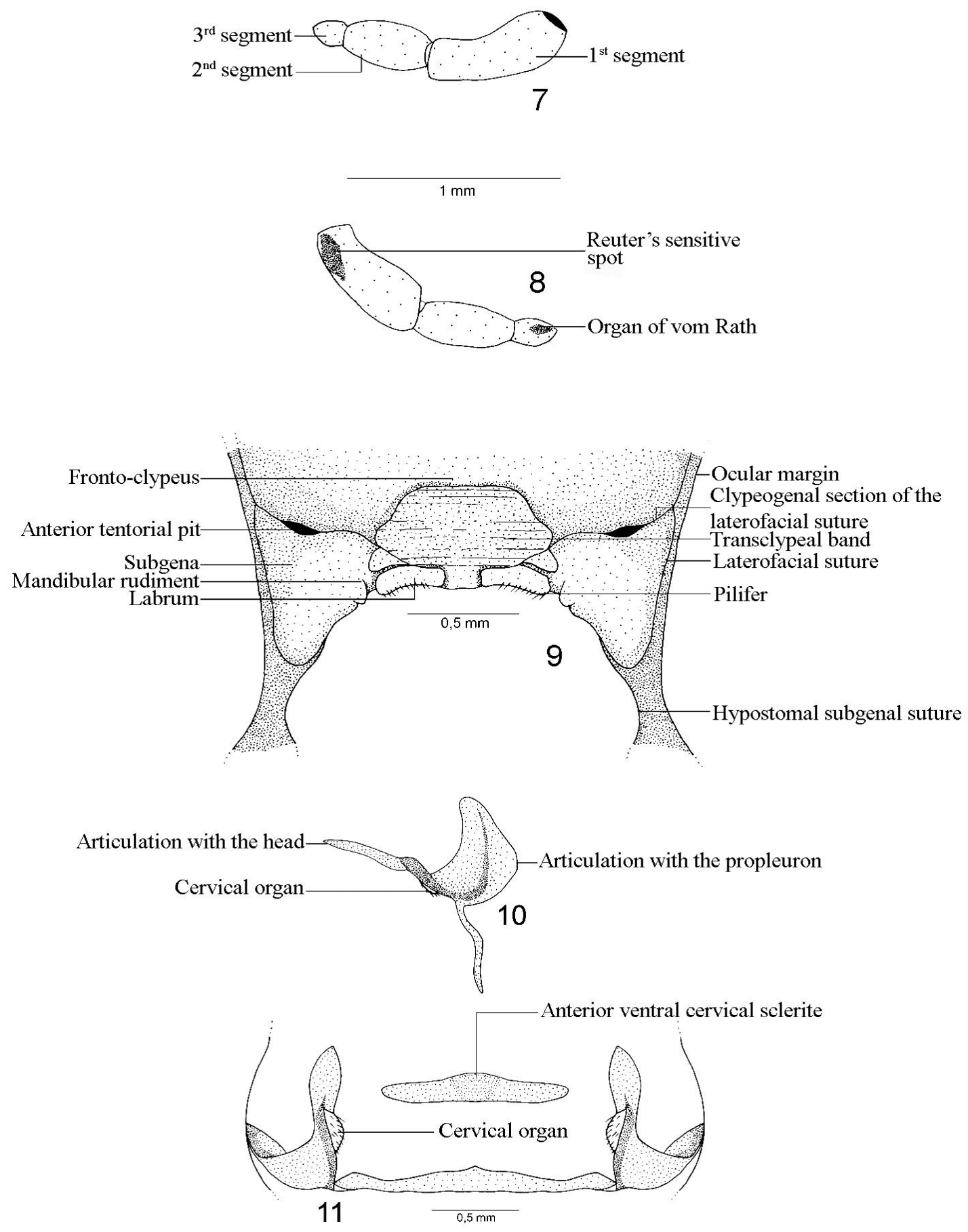

Figures 7 - 11 - Heraclides anchisiades capys: 7 - 8 - labial palp: 7 - external view. 8 - inner view. 9 - detailed view of the head (pilifer and mandibular rudiment). $10-11$ - cervical region: 10 - lateral view. 11 - ventral view. 

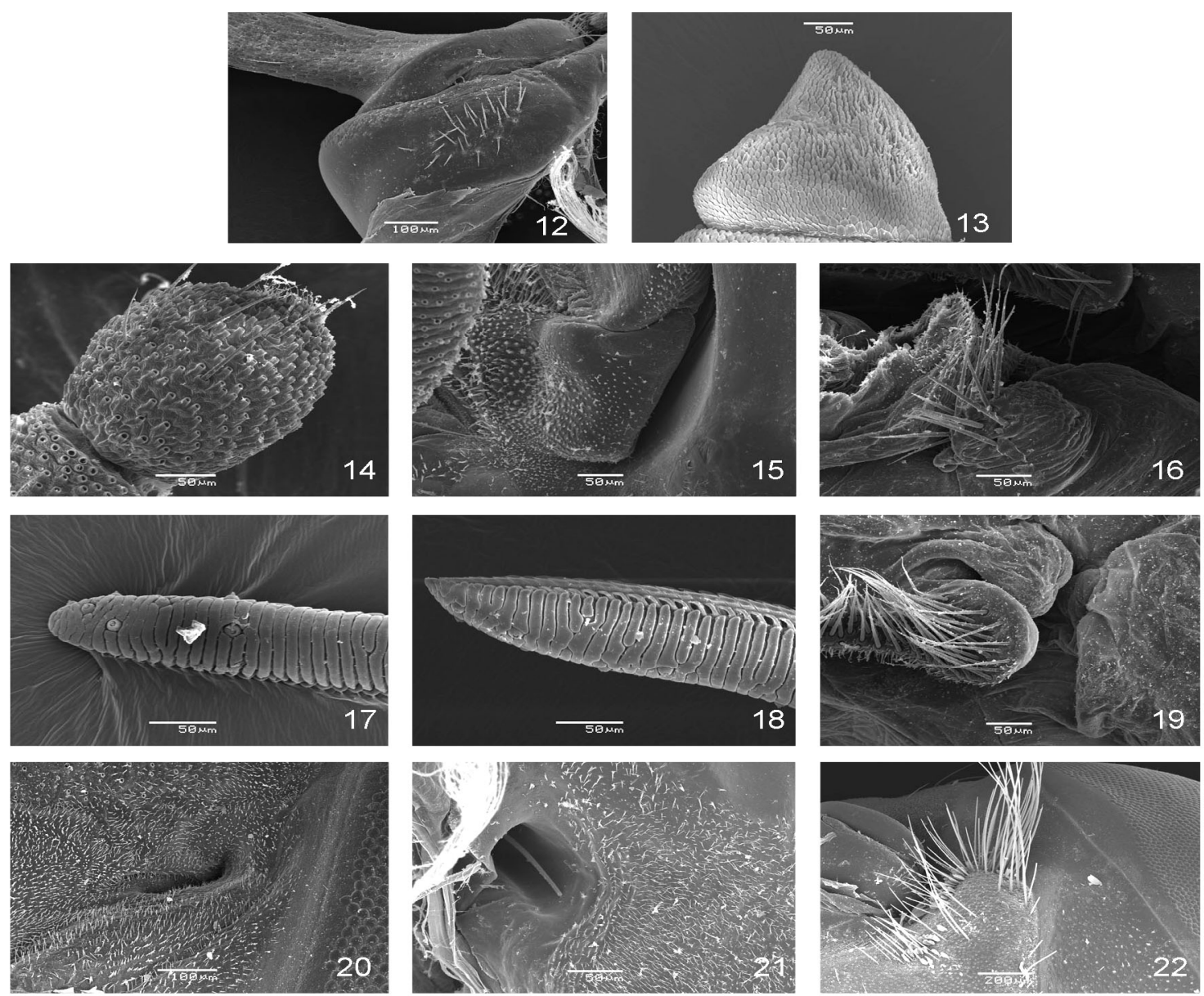

Figures 12 - 22 - Heraclides anchisiades capys: 12 - 13 - antenna: 12 - scape with sensitive area. 13 - distal flagellomere. 14 - distal segment of the labial palp. 15 - cardo. 16 rudimental maxillary palp. 17 - 18 - galea. 19 - pilifer and mandibular rudiment. 20 - anterior tentorial pit. 21 - posterior tentorial pit. 22 - chaetosema.

\section{ACKNOWLEDGMENTS}

We acknowledge the assistance of the Center of Electronic Microscopy of the Universidade Federal do Paraná for the elaboration of the photographical materials.

\section{RESUMO}

O propósito deste estudo foi evidenciar os componentes morfológicos da cabeça, seus apêndices cefálicos e da região cervical dos adultos de Heraclides anchisiades capys (Hübner, [1809]), visando um enfoque comparativo com outros Papilionoidea e Hesperioidea. A morfologia foi descrita através de ilustrações e microscopia eletrônica de varredura. Dentre os caracteres morfológicos encontrados destacam-se: presença de banda transclipeal, sutura laterofacial em vista ventral próxima da metade da margem ocular de aspecto convexo e presença de rudimento de palpo maxilar. União dos escleritos cervicais ventromedianamente; esclerito cervical ventral anterior situado anteriormente à união dos escleritos laterais.

\section{REFERENCES}

Bilotta, I. G. (1992), Morfologia Comparada da Cabeça das Espécies Sulbrasileiras de Morphinae (Lepidoptera: Nymphalidae). Revista Brasileira de Zoologia, 9 (3), 261 - 271.

Bilotta, I. G. (1994), Morfologia Comparada do Tórax das Espécies Sulbrasileiras de Morphinae (Lepidoptera: Nymphalidae). Revista Brasileira de Zoologia, 11 (4), 691 - 713. 
Bilotta, I. G. (1994), Morfologia Comparada do Abdome das Espécies Sulbrasileiras de Morphinae (Lepidoptera: Nymphalidae). Revista Brasileira de Zoologia, 11 (4), 737 - 748.

Bizarro, J. M. S.; Casagrande, M. M. and Mielke, O. H. H. (2003), Morfologia externa de Thyridia psidii cetoides (Rosemberg and Talbot). I. Cabeça e apêndices (Lepidoptera, Nymphalidae, Ithomiinae). Revista Brasileira de Zoologia, 20 (2), 279 - 284.

Bizarro, J. M. S.; Casagrande, M. M. and Mielke, O. H. H. (2003), Morfologia externa de Thyridia psidii cetoides (Rosemberg and Talbot) II. Tórax e appendices (Lepidoptera, Nymphalidae, Ithomiinae). Revista Brasileira de Zoologia, 20 (3), 419 - 425.

Bizarro, J. M. S; Casagrande, M. M. and Mielke, O. H. H. (2003), Morfologia externa de Thyridia psidii cetoides (Rosenberg and Talbot) (Lepidoptera, Nymphalidae, Ithomiinae). III. Abdome e apêndices. Revista Brasileira de Zoologia, 20 (4), 681 - 684.

Burns, J. M.; Janzen, D. H.; Hajibabaei, M.; Hallwachs W. and Herbert, P. D. N. (2007), DNA Barcodes of closely related (But morphologically and ecologically distinct) species of skipper butterflies (Hesperiidae) can differ by only one to three nucleotides. Journal of the Lepidopterists' Society, 61 (3), 138 - 153.

Casagrande, M. M. (1979), Sobre Caligo beltrao (Illiger). II: Morfologia externa da cabeça do adulto (Lepidóptera, Satyridae, Brassolinae). Revista Brasileira de Biologia, 39 (1), 223 - 227.

Casagrande, M. M. (1979), Sobre Caligo beltrao (Illiger). III: Morfologia externa do adulto - tórax. (Lepidoptera, Satyridae, Brassolinae). Revista Brasileira de Biologia, 39 (2), 347 - 355.

Casagrande, M. M. (1979), Sobre Caligo beltrao (Illiger). IV: Morfologia externa do adulto - abdome (Lepidoptera, Satyridae, Brassolinae). Revista Brasileira de Biologia, 39 (3), 711 - 716.

Duarte, M.; Casagrande, M. M. and Mielke, O. H. H. (2001), Morfologia externa do adulto de Hemiargus hanno (Stoll) (Lepidoptera, Lycaenidae, Polyommatinae, Polyommatini). I. Cabeça. Revista Brasileira de Zoologia, 18 (1), 225 - 238.

Duarte M. (2007), Morfologia externa do adulto de Hemiargus hanno (Stoll) (Lepidoptera, Lycaenidae, Polyommatinae, Polymmatini) II. Região cervical, tórax e abdome. Iheringia, Série Zoologia, 97 (2), 194 - 206.

Ehrlich, P. R. (1958), The integumental anatomy of the monarch butterfly Danaus plexippus L., (Lepidoptera: Danaidae). The University of Kansas Science Bulletin, 38, 1315 - 1349.

Ehrlich, P. R. (1960), The integumental anatomy of the silver-spotted skipper, Epargyreus clarus Cramer (Lepidoptera - Hesperiidae). Microentomology, 24, 1 $-23$.
Lamas, G. (ed.) (2004), Atlas of Neotropical Lepidoptera. Checklist: part 4A. Hesperioidea Papilionoidea. Vol. 5A. USA. Scientific publishers, 439p.

Madden, A. H. (1944). The external morphology of the Tobacco Hornworm (Lepidoptera, Sphingidae). Annals of the Entomological Society of America, 37, $145-160$.

Matsuda, R. (1965), Morphology and evolution of the insect head. The American Entomological Institute, 4, 1 - 334.

Mielke, C. G. C.; Mielke, O. H. H. and Casagrande, M. M. (2004), Estudo comparado de morfologia externa de Zaretis itys itylus (Westwood) e Agrias claudina anneta (Gray) (Lepidoptera, Nymphalidae, Charaxinae) I. Cabeça, apêndices e região cervical. Revista Brasileira de Zoologia, 21 (2), 357 -369.

Mielke, C. G. C.; Mielke, O. H. H. and Casagrande, M. M. (2004), Estudo comparado da morfologia externa de Zaretis itys itylus (Westwood) e Agrias claudina anneta (Gray) (Lepidoptera, Nymphalidae, Charaxinae) II. Tórax e apêndices. Revista Brasileira de Zoologia, 21 (3), 421 - 433.

Mielke, C. G. C.; Mielke, O. H. H. and Casagrande, M. M. (2004), Estudo comparado de morfologia externa de Zaretis itys itylus (Westwood) e Agrias claudina annetta (Gray). (Lepidoptera, Nymphalidae, Charaxinae) III. Abdome. Revista Brasileira de Zoologia, 21 (4), 905 - 912.

Miller, J. Y. (1971), The head capsule of selected Hesperioidea. Journal of Research on the Lepidoptera, 9 (4), 193-214. 1970 (1971).

Scoble, M. J. (1992), The Lepidoptera : form, function and diversity. Natural History Museum Publications. Oxford University Press, 404p.

Snodgrass, R. E. (1935), Principles of insect morphology. McGraw-Hill Book Company. New York and London. 667 pp., 319 figs.

Sorensen, J. T. (1980), An integumental anatomy for the butterfly Glaucopsyche lygdamus (Lepidoptera: Lycaenidae): a morphological terminology and homology. Zoological Journal of the Linnean Society, 70, 55 - 101.

Srivastava, K. P. (1961), Studies on the lemon butterfly Papilio demoleus L. (Lepidoptera). II Skeleto muscular mechanism (cervix and prothorax). Indian Journal of Entomology, 23, 202 - 213.

Received: December 23, 2008; Revised: May 11, 2009; Accepted: April 13, 2010. 